\title{
Feasible Deleveraging Options for Chinese Corporations: The Experiences of the United States and Japan
}

\author{
Jiaming Lin
}

PhD candidate, School of Economics, Central University of Finance and Economics, No. 39 South College Road, Haidian District, Beijing, China.

\begin{abstract}
Non-financial sector's leverage ratio of China has been rising rapidly after the 2008 financial crisis, and it is mainly manifested by the high debt leverage ratio of the non-financial corporations' sector, while this structural contradiction has not been apparent in developed countries and other emerging market countries. This paper takes the United States and Japan as research objects, comparatively analyzes the feature and countermeasures of debt leverage in the United States after the 2008 financial crisis and Japan's post-1990 financial crisis. Based on the actual situation of Chinese corporations' leverage, the reasonable transfer of leverage between macro-sectors (government sector, households sector and nonfinancial corporations sector), the gradual elimination of backward production capacity, and the improvement of the company's production and operation capabilities are of great significance to the high debt leverage of Chinese corporations.
\end{abstract}

Keywords-Chinese non-financial companies; deleveraging; experience comparison.

\section{INTRODUCTION}

After the 2008 financial crisis, in order to stimulate the global economy recovery, many countries have taken "rescue the market" measures. The Federal Reserve announced the "reducing quasi-interest rate" and "quantitative easing" policies. The Chinese government launched a series of measures to expand domestic demand, the so-called "four trillion" plan in November 2008. A series of recovery plans have a direct positive effect to economic growth, but they have also brought problems of rising prices, excess liquidity, and high leverage.

The high debt leverage ratio of China's non-financial corporation sector, is not only reflected in the entire time span after the financial crisis, but also in the same period of comparison with other countries in the world. According to the BIS data, the debt leverage ratio of Chinese non-financial companies continued to rise from 2006 to
2018, and has far exceeded the world average level and developed countries' level, and has maintained a high level of more than $120 \%$ for 10 consecutive years.

According to classical economic theory, Economic growth requires the stimulation of debt leverage, but excessive debt leverage is definitely not conducive to the sustained growth of the macro economy. Facing the same problems of debt increasing after the crisis, why can the debt leverage ratio of non-financial companies in developed countries be able to fall back quickly and maintain stability, but China is showing the phenomenon of "braking failure"? This paper analyses the leverage feature and countermeasures of the United States after the financial crisis in 2008 and Japan after the 1990 economic crisis, compares the results of the two countries, and provides policy recommendations for Chinese corporations deleveraging. 


\section{CURRENT SITUATION OF CHINESE CORPORATIONS' DEBT LEVERAGE}

The non-financial economy consists of the non-financial corporation sector, the households sector and the government sector three parts. From the perspective of the entire national economic system, the non-financial economy has always been the basis for the survival and development of human society.

According to the Bank for International Settlements (BIS), China's debt scale of non-financial sector has shown a rapid upward trend since 2009 (Figure 1), and the debt leverage ratio increased from $142.6 \%$ in the fourth quarter of 2008 to $158 \%$ in the first quarter of 2009 , the quarterly growth rate reached $13 \%$. As of the second quarter of 2019 , China's non-financial economy debt leverage ratio has reached 261.5\%. According Cecchetti et al. (2011) relevant research on OECD countries: the threshold of non-financial sector and economic growth is about 90\%. Excessive leverage will have a negative impact on total factor productivity. The non-financial sector's debt leverage ratio of China is already overloaded and is likely to have a negative impact on economy growth.

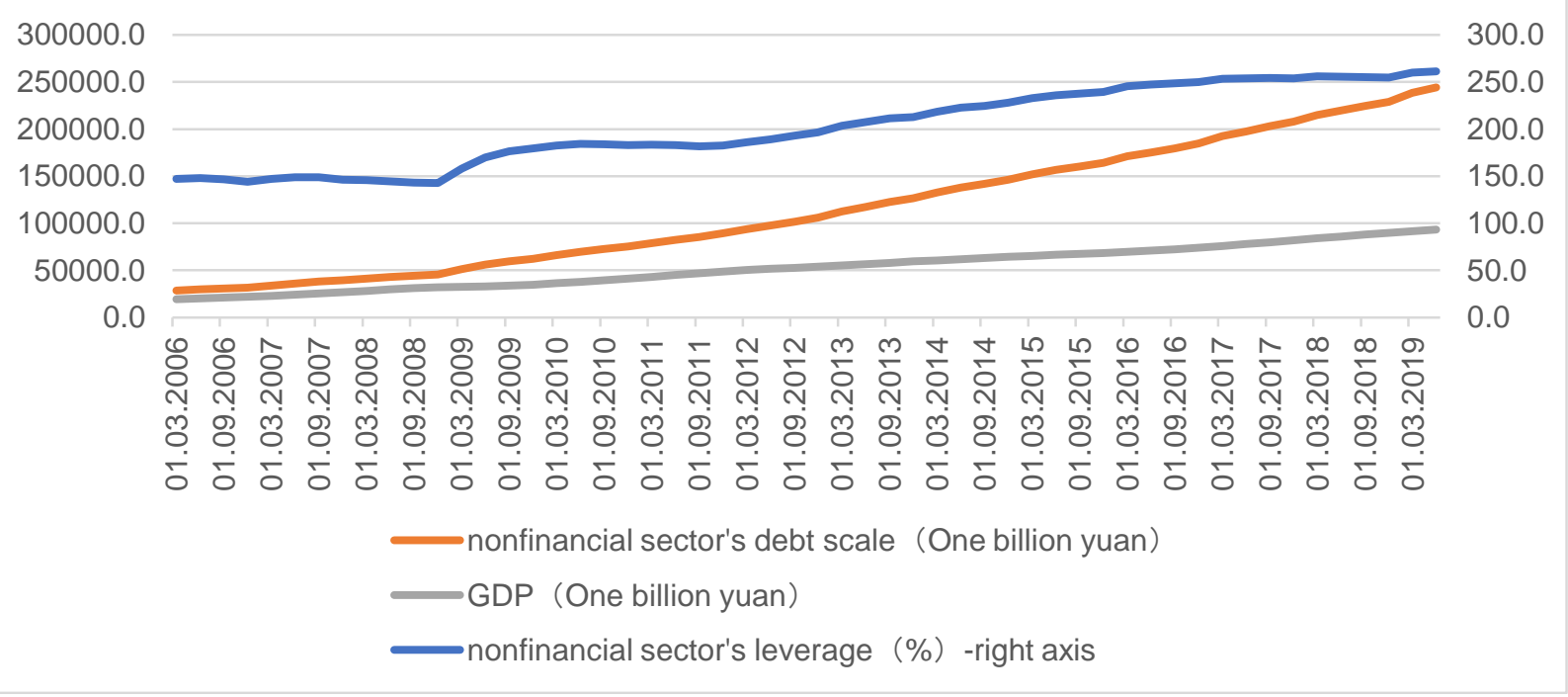

Fig.1: Debt scale and leverage ratio of china's non-financial sector (2006-2018)

Data resource : BIS

As the composition of the non-financial economy, continuing to decompose the debt leverage, it can be found that the non-financial corporations' sector has the highest proportion of debt leverage in the entire non-financial economy (figure 2).

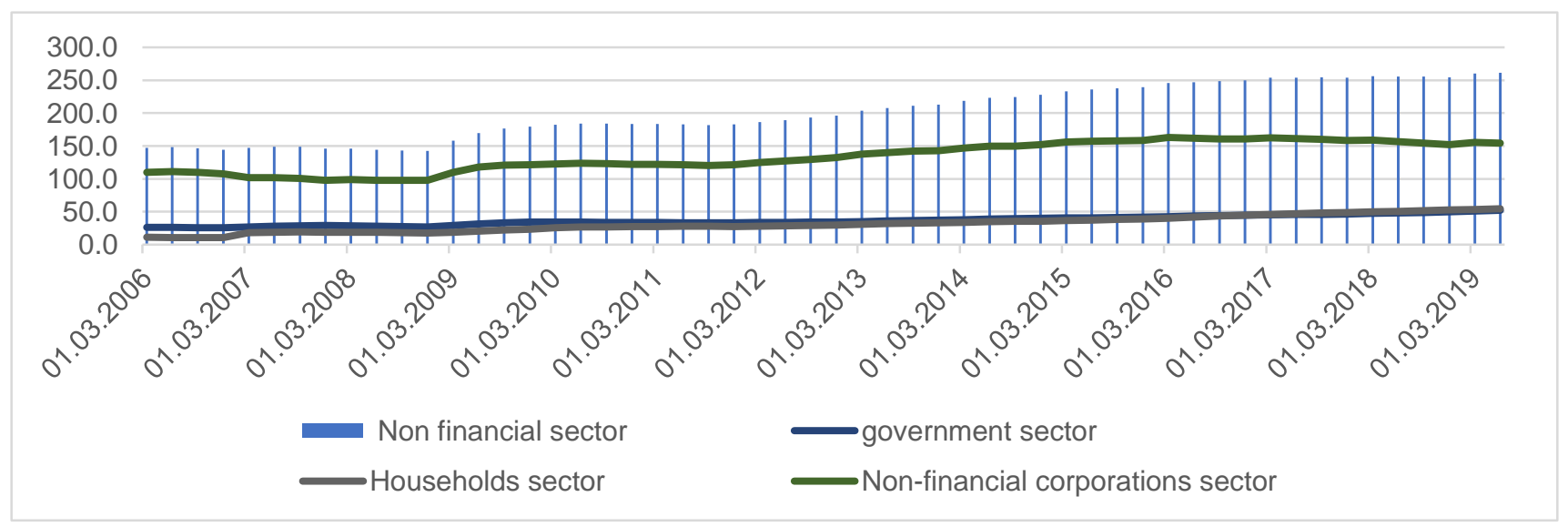

Fig.2: Debt leverage of the composition of China's non-financial sector (2006-2018)

Data resource : BIS 


\section{INTERNATIONAL COMPARISON OF DEBT LEVERAGE IN NON-FINANCIAL SECTOR}

The non-financial corporations are important parts of the macro economy. The changes of its debt leverage ratio are closely related to the changes in the leverage of the government and household sectors. As far as China is concerned, the high level of non-financial debt leverage is mainly concentrated in the non-financial corporation sector. Do the other countries in the world face the same problem?

(1) debt leverage of nonfinancial sector

Figure 3 describes the non-financial sector's debt leverage ratio of the United States, Japan, China, emerging market countries, developed countries and average level of all reporting countries.

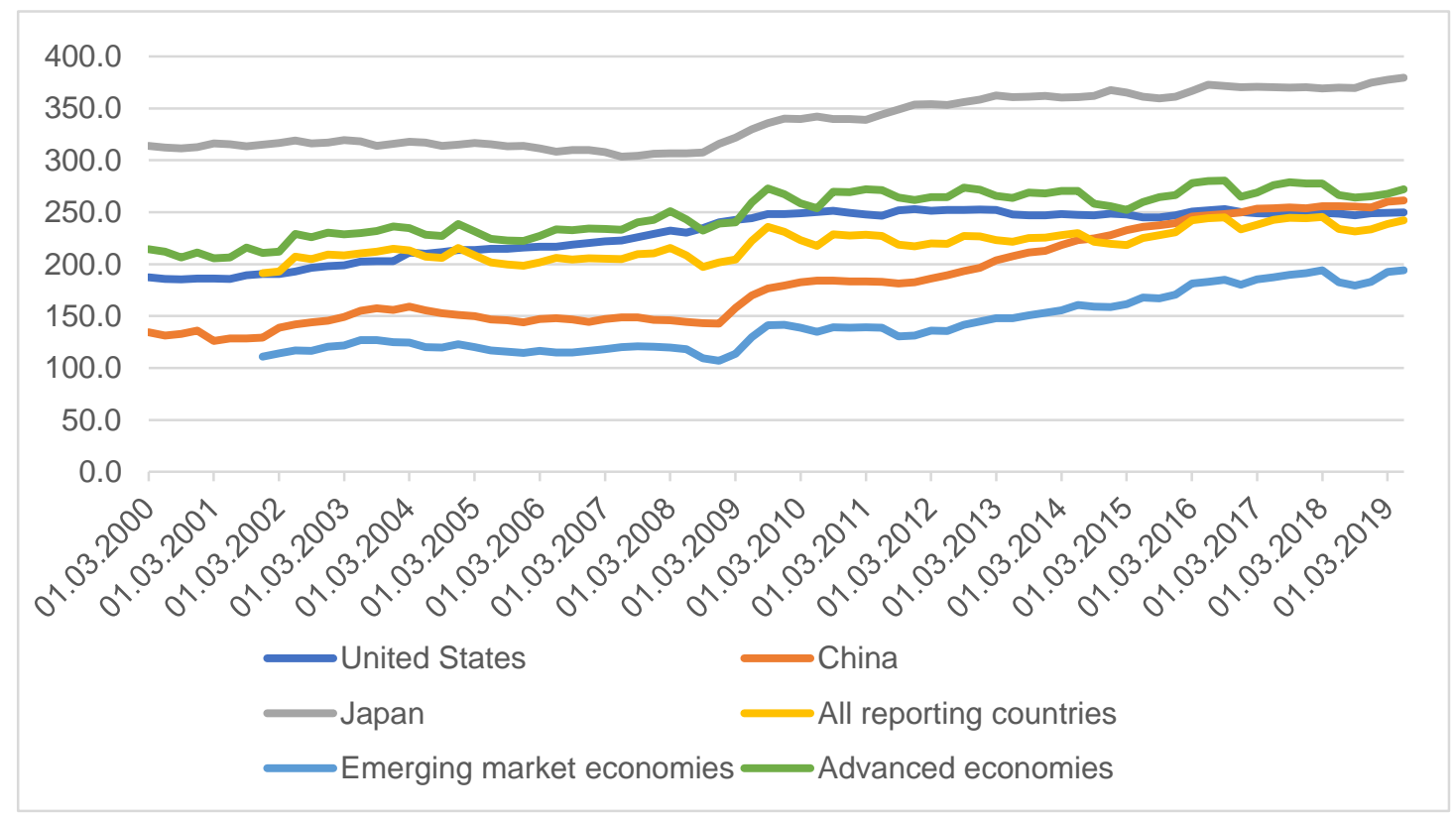

Fig.3: debt leverage of nonfinancial sector (2000-2019)

\section{Data resource : BIS}

According to Figure 3, there are the following findings: Firstly, after the financial crisis, the nonfinancial sector's debt leverage ratio of all countries has increased significantly. Secondly, Japan 's nonfinancial sector has the highest debt leverage ratio, reaching $313.8 \%$ in the first quarter of 2000. As of the second quarter of 2019, its debt leverage ratio has reached $379.6 \%$, while the average level of developed countries during the same period was $272.3 \%$. Thirdly, the US nonfinancial sector's debt leverage ratio is lower than the average level of developed countries, and has remained stable after the financial crisis. Fourthly,
China 's nonfinancial sector's debt leverage ratio is much higher than the average level of emerging market countries, and has shown sustained growth after the financial crisis. It is now close to the average level of the United States and developed countries.

(2) debt leverage of nonfinancial corporations' sector

Figure4 describes the non-financial corporation sector's debt leverage ratio of the United States, Japan, China, emerging market countries, developed countriesand average level of all reporting countries. 


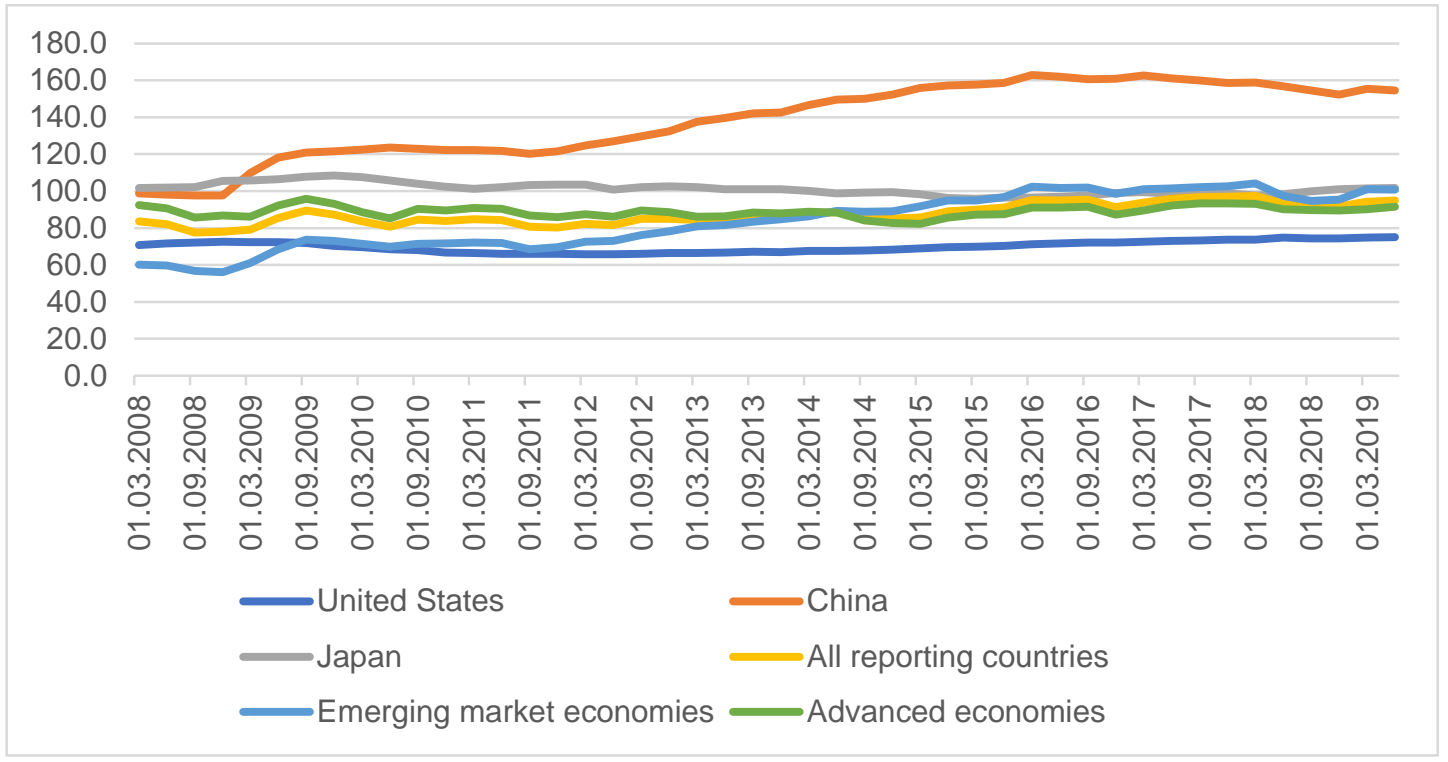

Fig.4: Debt leverage of non-financial corporation sector (2008-2019)

Data resource : BIS

According to Figure 4, it can be found that, the first is the debt leverage ratio of Chinese corporation exceeds that of the other countries. it has increased from $98.7 \%$ in the first quarter of 2008 to $154.5 \%$ in the second quarter of 2019. This differentiation is particularly evident after the financial crisis, and at the same time, a new round of rises began around 2012, with the highest point at $162.8 \%$ in the first quarter of 2016. The second, the non-financial corporations' debt leverage ratio of Japan and the United States have both remained stable. On the whole, the debt leverage ratio of the US corporation sector has rebounded in recent years, but it is still lower than the average level of developed countries. This may be related to post-crisis policy measures and its own developed capital market structure.

(3) debt leverage of households sector

Figure 5 describes the households sector's debt leverage ratio of the United States, Japan, China, emerging market countries, developed countries and average level of all reporting countries.
There are the following findings: Firstly, after the financial crisis, the household sector in developed countries decreased leverage, and the emerging market countries increased leverage, and there is a tendency to move closer to the sample average level, which may be related to the household savings rate and consumption habits among different countries. Secondly, Japan 's households sector debt leverage ratio has been stable at around $60 \%$. This may be related to Japan 's experience of the real estate bubble crisis in the 1990s and the adjustment of household consumption trends. Thirdly, although the debt leverage ratio of the household sector in developed countries has declined, it is still higher than that in emerging market countries. It can be inferred that the debt ratio of the household sector depends not only on consumption habits, but also is largely related to the level of economic development and per capita disposable income of the family. 


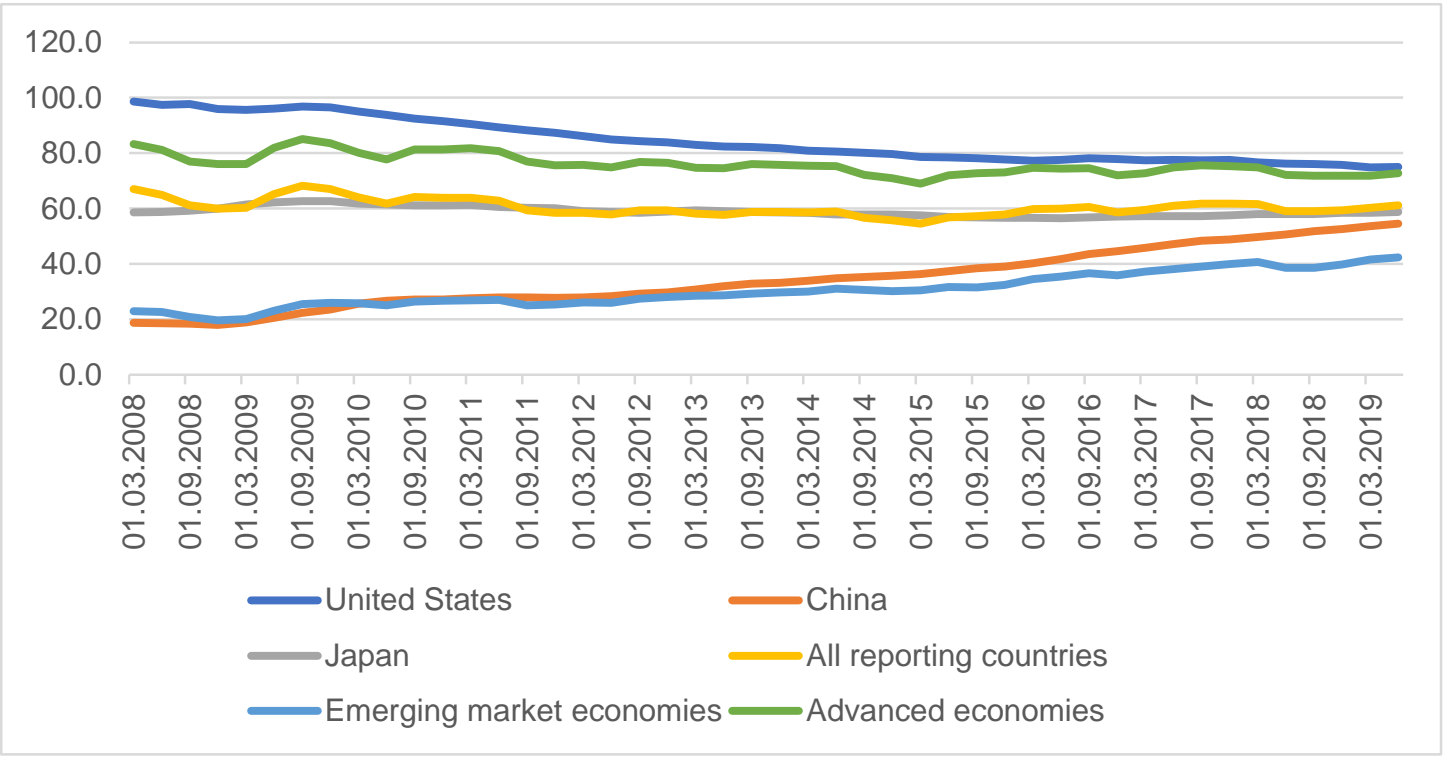

Fig.5: Debt leverage of households sector (2008-2019)

Data resource : BIS

(4) debt leverage of government sector

Figure 6 describes the government sector's debt leverage ratio of the United States, Japan, China, emerging market countries, developed countries and average level of all reporting countries.

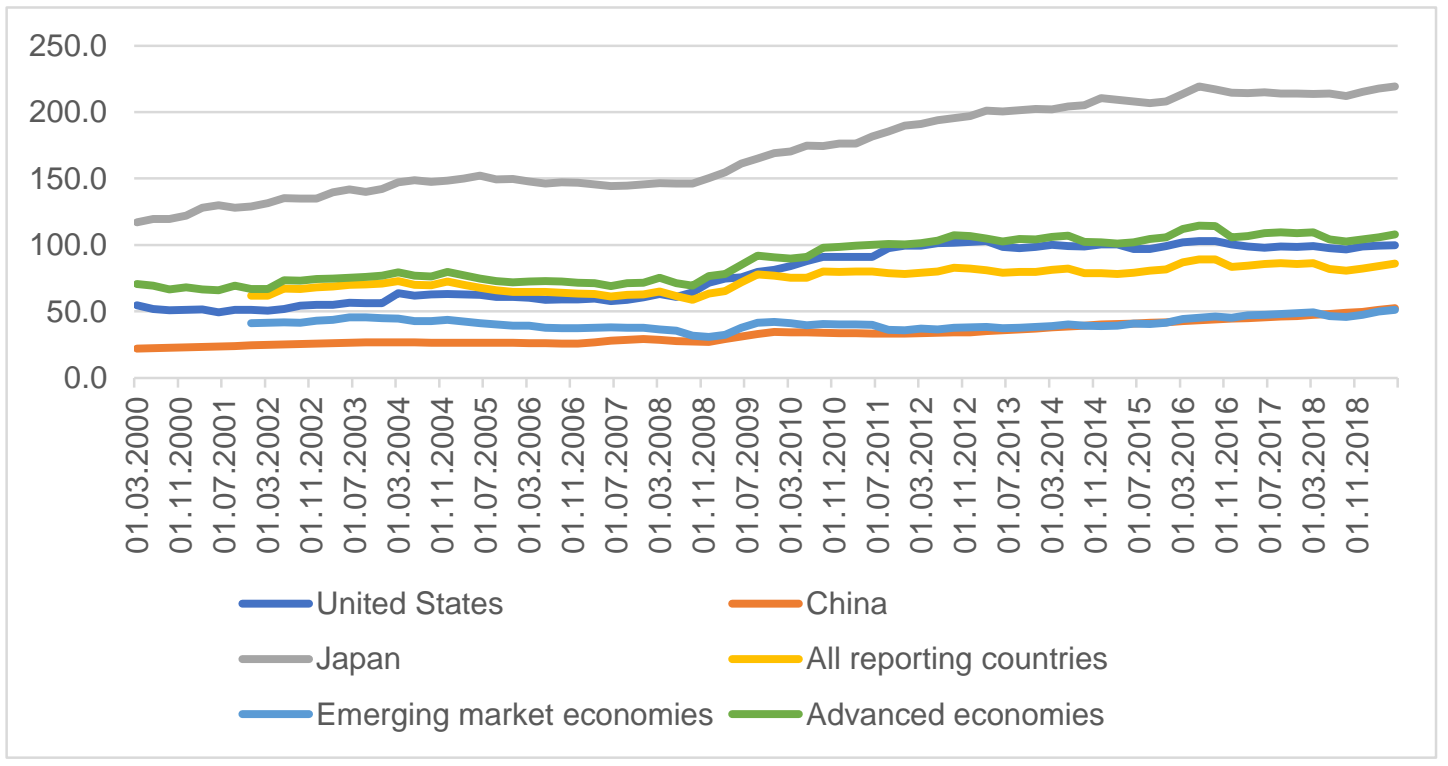

Fig.6: Debt leverage of government sector (2000-2019)

Data resource : BIS

There are the following findings: Firstly, after the financial crisis, the debt leverage ratio of government sector in all economies has increased. The second is that Japan 's government sector debt leverage ratio far exceeds that of other economies. It can be concluded that its government sector's debt is the main component of
Japan 's non-financial sector. Thirdly, the debt leverage ratio of government sector in emerging market countries is lower than that in developed countries, and it remains relatively low. Fourthly, the debt leverage ratio of the Chinese government is at a relatively low level. In contrast, the Chinese government has considerable room to consider 
implementing expansionary fiscal policies.

Through the above comparisons, the non-financial sector's leverage ratio of emerging market countries is lower than that of developed countries, and Japan has the highest debt leverage ratio, which continues to exceed $300 \%$ and has remained high. In terms of time series, after the financial crisis in 2008, the debt leverage ratio of non-financial sector of all countries has increased significantly, and the debt structure of different sectors in the non-financial economy has clearly changed since 2008. Specifically, Chinese corporation sector's debt leverage accounts for more than $70 \%$ of the non-financial economy, while Japanese government sector's debt leverage ratio accounts for more than $50 \%$ of the non-financial economy, the US government sector and household sector account for a higher proportion compared with the corporation sector.

The special debt structure is inseparable from different countries' economic structure. The high debt leverage ratio of Chinese non-financial corporations is due to economic stimulus after the financial crisis, which has resulted in overproduction in some industries. the high debt leverage ratio of the Japanese government is due to alleviate the debt burden of the households and corporations afterthe bursting of the real estate bubble. The US households sector's debt accounted for a relatively high proportion, due to the debt-consuming consumption habits, and the higher proportion of US government debt stems from the fiscal policy after the financial crisis.

\section{THE FEATURE AND COUNTER MEASURES OF THE U.S. CORPORATIONS' LEVERAGE}

4.1 Trend of the U.S. corporations' leverage

Figure 7 describes the debt leverage ratio of different sectors of the non-financial economy of the U.S.

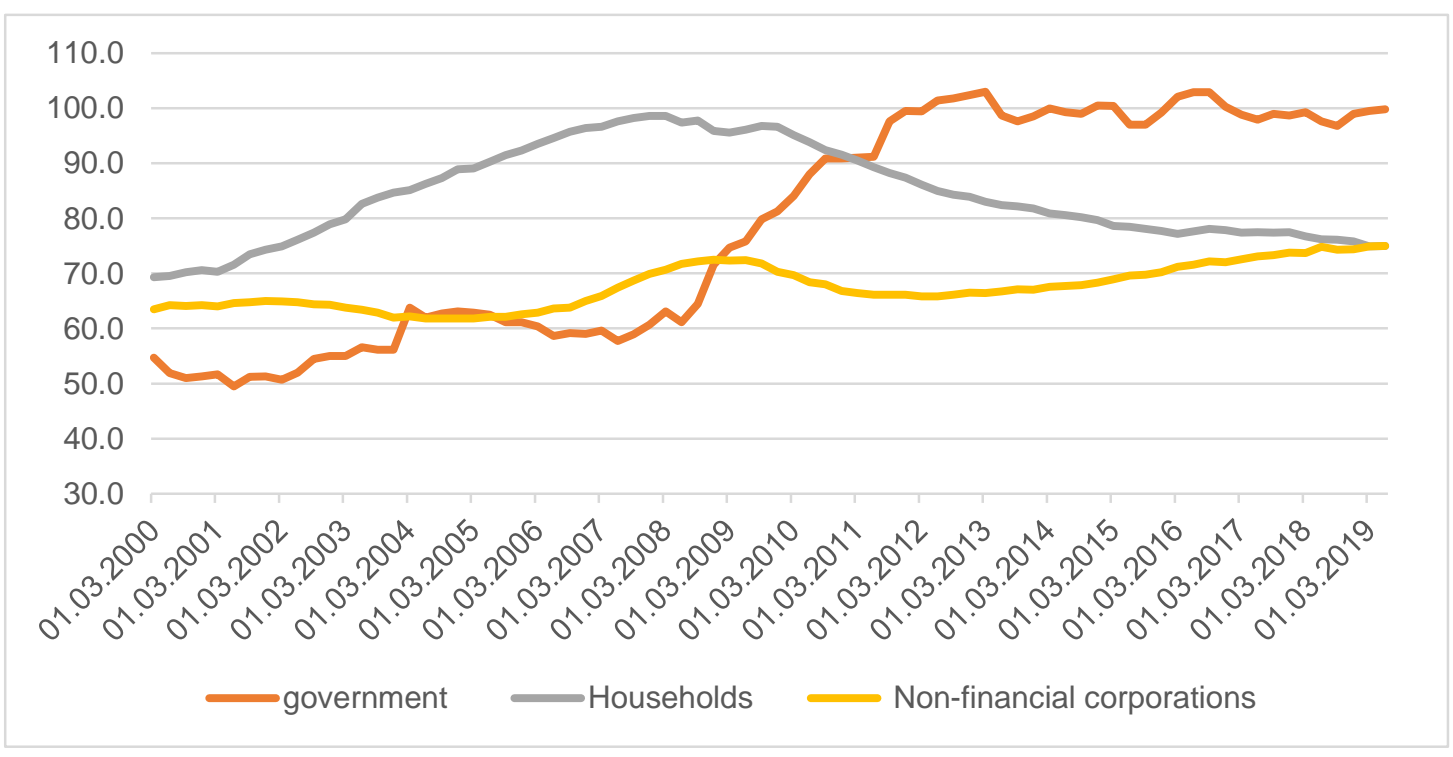

Fig.7: Debt leverage composition ofthe U.S. non-financial sector (2000-2019)

\section{Data resource : BIS}

Before the financial crisis, the debt leverage ratio of the household sector far exceeded that of the government and the corporate sector; after the financial crisis, the leverage ratio of the government sector increased, and the leverage ratio of the household sector decreased. Secondly, the debt leverage ratio of the corporation sector remained stable, and began to rise steadily after the impact of the financial crisis. This is related to the "re-industrialization" strategy implemented by the Obama administration. Thirdly, the debt leverage ratio of the corporation sector is lower than the leverage ratio of the government sector and the household sector. Before the financial crisis, the household sector showed a clear tendency to lead consumption, andthe emergence of financial innovation tools such as asset securitization boosted the family sector 's debt bearing capacity. After the financial crisis, the asset bubble burst and 
the leverage ratio of the household sector fell rapidly. In order to stimulate economic growth, the US government implemented an active fiscal policy, expanded infrastructure construction, and actively increased the leverage of the government sector.

\subsection{Countermeasures and Effects of deleveraging}

(1) Counter measures of deleveraging in the U.S.

The U.S. deleveraging experience is mainly reflected in two aspects. One is quantitative easing monetary policy, providing liquidity for the financial market. The second is leverage transfer between economy sectors,reducing leverage in the household and corporation sectors, and increasing leverage in the government sector to hedge the debt risk of economic downturn through leverage shift.

Since 2008, the Fed has implemented four rounds of quantitative easing policies, implemented large-scale asset purchases to actively provide liquidity to the market. After the outbreak of the financial crisis, the Fed firstly increased the government assistance to the financial institutions in crisis as the "last lender", quickly supplemented the liquidity of the financial market, reduced the cost of credit by increasing government support, helping financial institutions gradually recover their balance sheets. The US government has expanded the scope of assistance and provided financial assistance to important industries and enterprises. For example, the US government provides emergency rescue programs to the auto industry and emergency loans to automakers to mitigate the risk of large-scale bankruptcy. On the one hand, the quantitative easing monetary policy brings lower interest rates and lower corporate financing costs, which greatly saves corporate expenditures and indirectly reduces the actual level of corporations' debt; On the other hand, lower interest rate levels stimulated a new round of prosperity in the US bond and stock markets, and eased the pressure on debt financing through the prosperity of the stock market.

Due to residents' consumption habits and asset securitization products with excessive concentration of leverage, before the outbreak of the financial crisis, US debt was mainly concentrated in households and the financial sector. After the outbreak of the financial crisis, asset price bubbles burst and high debt leverage in the household and corporate sectors is unsustainable. The US government has implemented a proactive fiscal policy to stimulate aggregate demand and expand government spending through programs such as large-scale infrastructure investment and improvement of people 's livelihood. On the one hand, it has realized the transfer of debts from residents and the financial sector, and on the other hand, it stimulated economic growth effectively,reduced the leverage ratio of residents and the financial sector.

(2)Effects of deleveraging in the U.S.

From the perspective of changes in the leverage ratio, the non-financial sector has shown a steady decline, the household and corporation sector have dropped significantly, and the government sector has increased significantly. After the financial crisis, the debt leverage ratio of the non-financial sector did not fluctuate significantly, and the stable debt scale and growth rate did not bring too much restriction on economic development. The household sector and the corporation sector have achieved a decline in debt leverage ratio. Stimulated by the economic recovery, the debt leverage ratio of the corporation sector has begun to rise steadily. The household sector debt leverage ratio was $98.6 \%$ in the first quarter of 2008 and $74.9 \%$ in the first quarter of 2019, which has successfully decreased by $23.7 \%$. After the adjustment of the corporations' sector in 2008-2010, it shows a steady upward trend. As the "last lender", the government department has eased the pressure on the household and corporation sectors through the rise of the debt leverage ratio in the short term, but the debt level remained relatively stable after the crisis. From the fourth quarter of 2011, the debt leverage of the government department basically fluctuated at the $100 \%$ level, and there was no continuous expansion of debt due to the inertia of the loose stimulus policy.

From the perspective of macroeconomic performance, the US economy has gradually emerged from the haze of the financial crisis due to effective deleveraging. The first is economic growth. The US economy began to enter the recovery process ahead of other countries in 2009, and maintained an average annual growth rate of about $2.3 \%$ after 2010. Secondly, the export trade situation.

The steady increase in the debt leverage of the corporate sector after the crisis also benefited from the 
"re-industrialization" strategy proposed by the Obama administration, which boosted exports by enhancing manufacturing, especially high-end manufacturing, and reversed the situation of excessive foreign trade deficits. According to figure 8 , the total value of US exports increased significantly after the crisis, rising from US $\$ 10,560.4$ billion in 2009 to US $\$ 16,455.3$ billion in 2019 , of which export growth was $21.04 \%$ in 2010 . Thirdly, the unemployment rate has continued to decline. After the financial crisis, a series of bailout strategies have also significantly improved the employment rate in the United States. According to figure 9, the unemployment rate of the 15-64-year-old labor force has dropped from $9.38 \%$ in 2009 to $3.72 \%$ in 2019 , and the unemployment rate has fallen. It also provides sufficient guarantee for the recovery of the US economy.

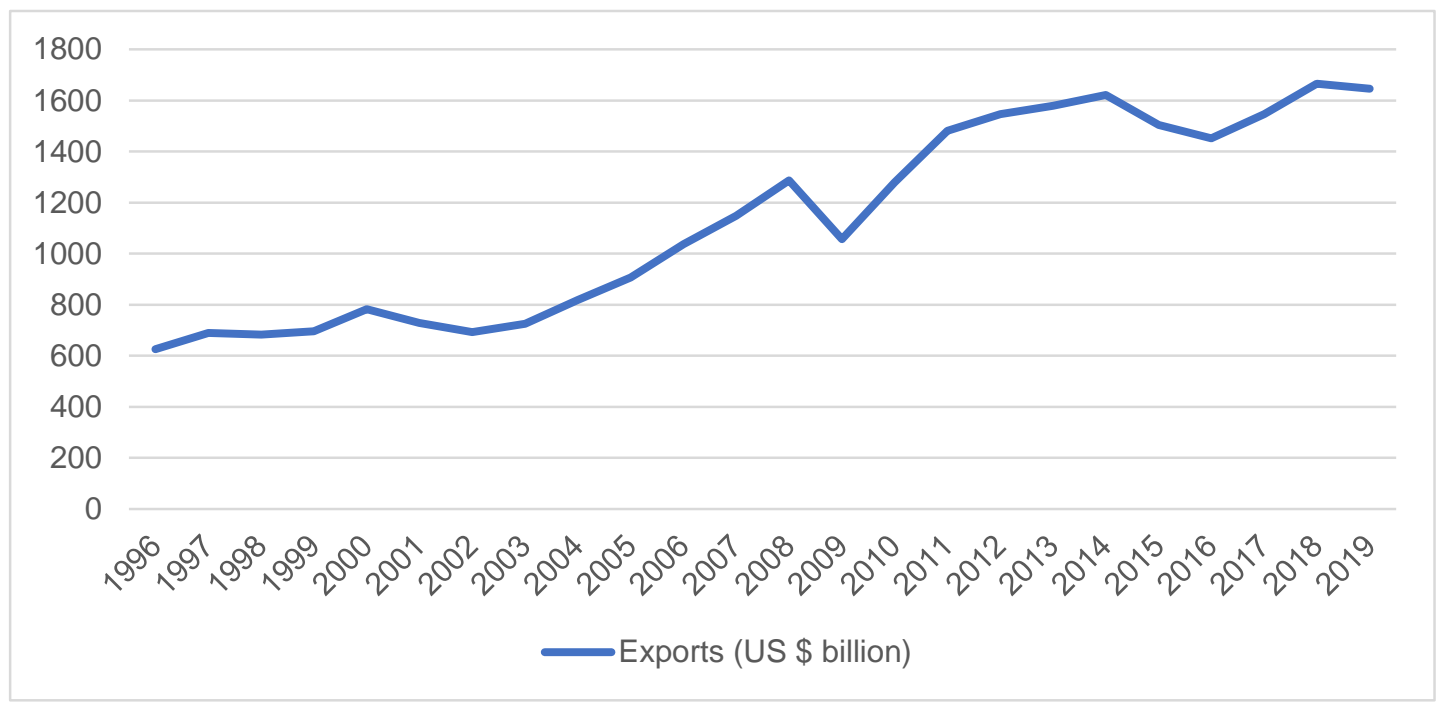

Fig.8: Exports of the U.S. (1996-2019)

Data resource : OECD countries' database

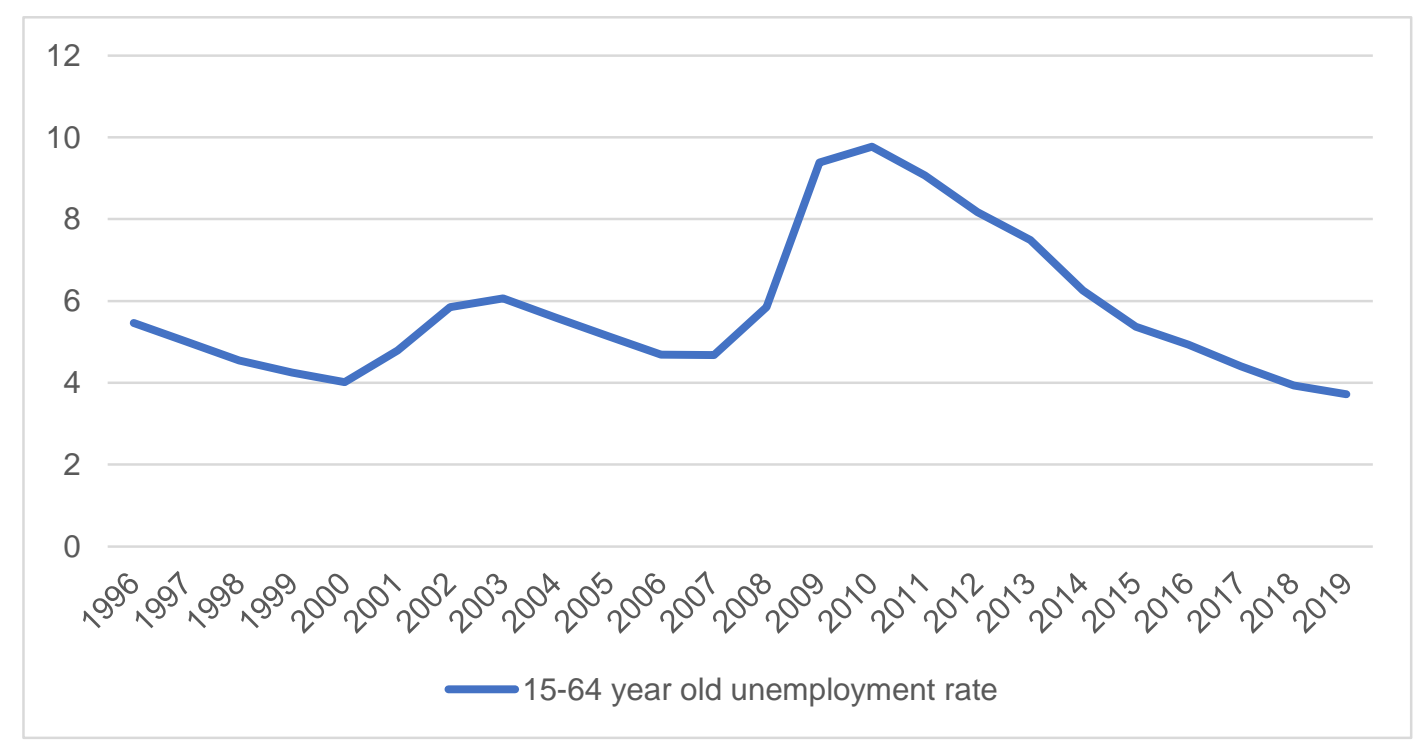

Fig.9: Unemployment rate of the 15-64-year-old labor force in the U.S. (1996-2019)

Data resource : OECD countries' database 


\section{THE FEATURE AND COUNTER MEASURES OF THE JAPANESE CORPORATIONS' LEVERAGE}

5.1 Trend of the Japanese corporations' leverage

Figure 10 describes the debt leverage ratio of different sectors of the non-financial economy of Japan.

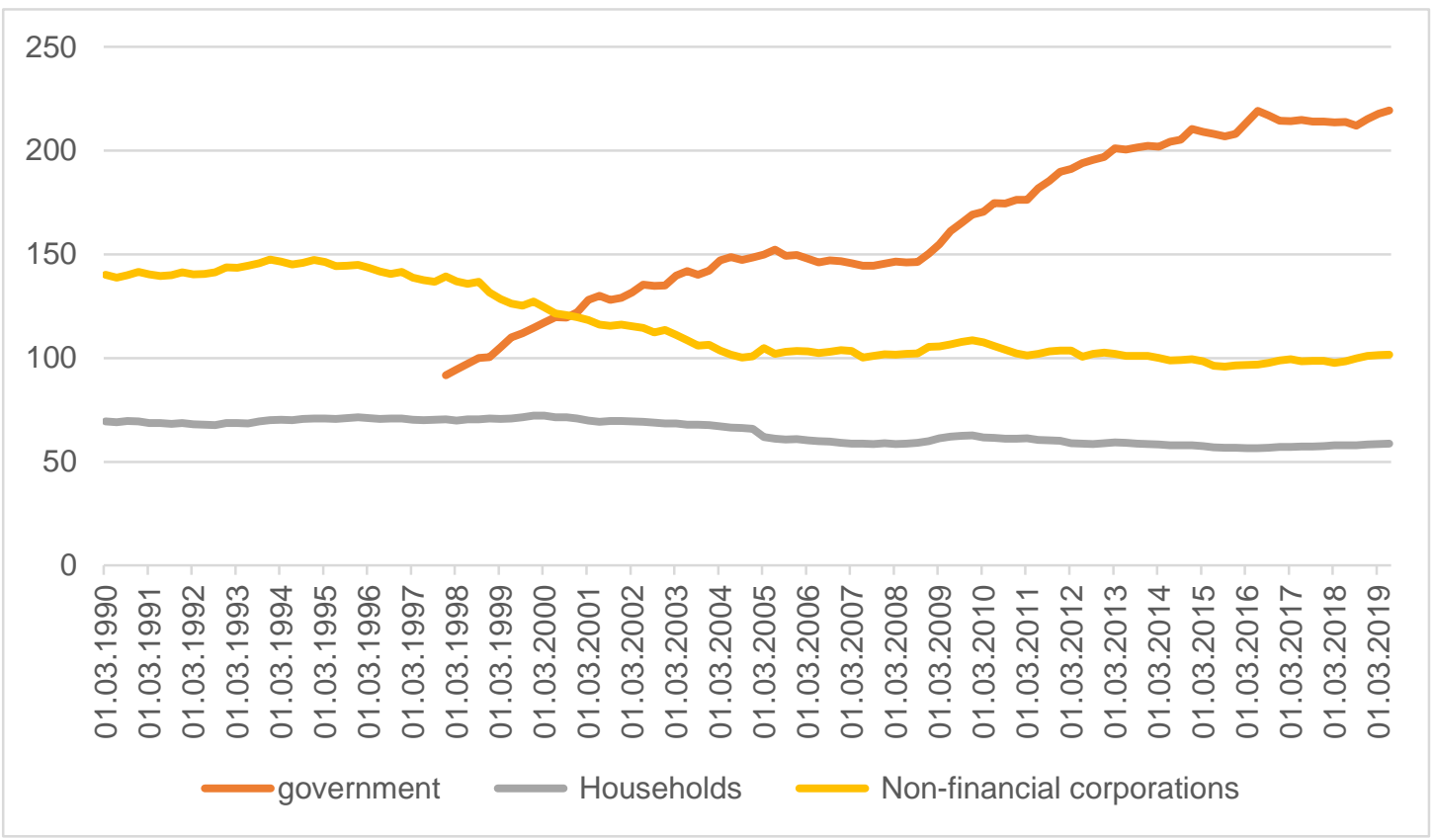

Fig.10: Debt leverage composition of the Japan non-financial sector (1990-2019)

Data resource : BIS

The following findings are found: Firstly, the debt leverage ratio of the Japanese government sector has risen all the way, far exceeding the household sector and the corporation sector, from $94.4 \%$ in the first quarter of 1998 to $150.2 \%$ in the fourth quarter of 2008. After the financial crisis the government's debt leverage ratio ushered in a new round of increasing, reaching $219.4 \%$ in the second quarter of 2019. Secondly, the leverage of household sector has been stable since the economic crisis in the 1990s, and has a slight downward trend. Thirdly, the debt leverage ratio of the corporation sector declined during the rising stage of government leverage ratio, which is currently maintained at about $100 \%$, which has fallen by about $40 \%-50 \%$ compared to the early 1990 s.

\subsection{Countermeasures and Effects of deleveraging}

(1) Countermeasures of deleveraging in Japan

Compared with the United States, Japan 's debt deleveraging has been bumpy since the 1990s crisis. After the real estate bubble burst, a large number of enterprises were insolvent and debt leverage was high, but the Japanese government did not take over financial institutions like the US government and quickly added liquidity to the market. Bankruptcy of corporate loans was extended, and a large number of "zombie" companies appeared, manifested by the high debt leverage ratio of enterprises.

After the real estate bubble burst, the debt leverage ratio of the corporation sector was high, reaching about $140 \%$ in 1990. In order to alleviate the debt predicament of the corporation sector, the Japanese government continued to increase the issuance of government bonds. By 2013, the issuance of Japanese government bonds was nearly five times as high as that of 1990. The increase in government bonds made the government 's debt leverage rise rapidly, the Japanese government debt leverage increased from $94.4 \%$ in the first quarter of 1998 to $150.2 \%$ in the fourth quarter of 2008. After the financial crisis, the government 's debt leverage ratio ushered in a new round of increase, reaching $219.4 \%$ in the second quarter of 2019. After a series of leveraged measures by the government, the debt leverage ratio of the corporation sector has declined, and it is 
currently maintained at about $100 \%$, which is about $40 \%$ $-50 \%$ lower than in the early 1990s. Although the debt leverage of the corporation sector has declined, we are concerned aboutwhether the accompanying excessive debt leverage of the government sector will cause new problems.

The Central Bank of Japan lowered the interest rate of loans many times. By 1991, the short-term interest rate was close to zero. From 2001 to 2008, Japan also adjusted its monetary policy many times, implemented quantitative easing strategies, and became the first country in the world to adopt a quantitative easing monetary policy. However, Japanese corporation's debt leverage did not decline as the United States did, the main point is that loosing monetary policy has not been converted into loosing credit policies. The large number of "zombie companies" cannot be effectively rescued by the government and banks, which indirectly leads to financial resources wasted. At the same time, due to the squeezing of credit by zombies, a large number of non-performing assets are concentrated in financial sectors such as banks, resulting in the financial sector's balance sheet not being significantly improved. This vicious circle makes quantitative easing monetary policy not really effective.

\section{(2)Effects of deleveraging in Japan}

From the comparison of the deleveraging strategies between the United States and Japan, it can be found that the two have basically adopted the same policies when dealing with the debt problem. Why is the path of deleveraging in Japan more tortuous than that of the United States? So far, Japanese government debt is still relatively high, and the level of economic growth is at a low level.

From the perspective of changes in leverage ratio, non-financial debt leverage ratio is still at a high level (313.8\% in 2000 and $379.6 \%$ as of the second quarter of 2019), which is mainly reflected in the increase of government sector's leverage after leverage transfer, significantly higher than other countries; the debt leverage of the corporation sector declined slightly, but also exceeded the average of the reporting countries.

From 1998 to 2019, Japan's GDP growth rate fluctuated violently, and the economic aggregate did not show a continuous increase, and it showed a more obvious decline between 2013 and 2015. In terms of economic growth, even in some years, negative growth has occurred, and the Japanese economy is still in an unstable state.

Compared with the United States, Japan's leverage transfer does not reflect the effectiveness of fiscal policy. On the one hand, the reason is that after the economic crisis, the government did not continue to inject liquidity support into the "zombie enterprise". Although the interest rate is low enough, but a large number of non-performing assets still accumulate on the balance sheets of financial institutions. Financial institutions are reluctant to expand credit scale, corporations also strive to minimize debt scale, the economy falls into a "liquidity trap." On the other hand, Japan's fiscal policy is different during different leaders' term of office. The policy adjustment makes expansionary fiscal policy not resonate with loose monetary policy in a short time, causing the fiscal stimulus policy does not work.

\section{SUGGESTION:FEASIBLE DELEVERAGING OPTIONS FOR CHINESE CORPORATIONS}

This paper selects Japan, which experienced the housing bubble crisis in 1990, and the United States, which experienced the financial crisis in 2008, as the analysis objects. It horizontally compares the debt leverage structure of the world's major economies, and compares the trend of the corporations' debt leverage of different countries from the time dimension; analyzing the policy measures and effectiveness of the United States and Japan in responding to the post-crisis corporation debt leverage issue, hoping to provide a reference for the adjustment of the debt leverage of Chinese corporations.

1. Leverage transfer. China's government and household sector debt leverage ratio is relatively low, and it can be considered to increase leverage in the government or households sector to achieve the leverage transfer. However, leverage transfer does not reduce debts, In the process of leverage transfer, special attention should be paid to the debt bearing capacity of the household and government sector, including the ability of households to manage their income and the support of government income.

2. Elimination of backward production capacity. Compared with the large amount of insolvency of corporate 
assets in the United States and Japan, although the debt leverage ratio of Chinese corporations is very high, it has a special structural characteristic. On the one hand, after the financial crisis, in order to stimulate economic growth, China implemented a "four trillion" fiscal plan, which promoted economic growth and also brought excess capacity in some industries. Thisrequires both Supply-side reform and demand-side expansion, and the transformation of excess capacity can be improved through the construction of the "Belt and Road" and overseas investment. On the other hand, the structural contradictions of Chinese corporations' leverage are reflected in many aspects. State-owned enterprises, real estate enterprises and non-listed enterprises are all problems that need to be solved, not only the adjustment of the enterprise itself, but also the measures of the national macro policy.

3. Improving the corporations' productivity. In the long run, in order to reduce the corporations' leverage ratio, it must be achieved by increasing corporations' productivity and maintaining long-term stable economic growth. The government needs to maintain monetary policy stability, provide appropriate liquidity, reduce the burden on enterprises, and support the development of the non-financial economy. At the same time, learning from the experience of the United States, it needs to broaden the financing channels of enterprises, develop a multi-level capital market, and reduce the difficulty of corporate financing in the stock market. The US "re-industrialization" strategy embodies the thinking of economic transformation. For that, it also needs to encourage enterprises to improve their independent innovation capabilities and rely on endogenous technological innovation to enhance their competitiveness. Promoting the development of high-tech enterprises through technological progress.

\section{REFERENCES}

[1] Cecchetti et al. (2011). The Real Effects of Debt. BIS Working Paper.

[2] Chen W, Xiong Q. (2017). International comparison of China's non-financial corporations' leverage ratio and countermeasure suggestions. International Finance Research.2: 3-11.

[3] Dalio R. (2014). How the economic machine works-leveraging and deleveraging. Economic Principles, New York: Bridgewater Associates.

[4] Devereux, MichaelB, Yetman, James. (2010). Financial Deleveraging And the International Transmission of Shocks. The International Financial Crisis and Policy Challenge in Asia and the Pacific.52:274-298.

[5] Hinrichsen S. (2008). The deleveraging cycle. IMF Economic Review. 55(1): 109-148.

[6] Hong Ch. (2018). Discussion on the Feasibility of Deleveraging in China-International Comparison and Countermeasures. New Finance. 2: 20-25.

[7] Li X. (2017). The deleveraging experiences of Japan and the US. New Finance. 6: 4-8.

[8] Lou F. (2018). Practice and Enlightenment of Deleveraging in the United States. Gansu Finance, 10: 17-20.

[9] P Benignop, GB Eggertsson, F Romei. (2015). Dynamic Debt Deleveraging And Optimal Monetary Policy. NBER Working paper.

[10] Zhao L. (2018). Research on the leverage ratio and risks of China's finance, enterprises and government departments. Jilin University.

[11] Zhou J, Wang Y, Han X. (2018). Deleveraging, Leverage and Monetary Policy Transmission_— Research Based on New Keynesian Dynamic General Equilibrium. International Finance Research.4: 24-34. 